Stefan H. Kaszyński

Poznań

\title{
SZYFRY TOŻSAMOŚCI LITERACKIEJ W HABSBURSKICH KRAJOBRAZACH
}

\section{Austriacki sposób czytania świata}

Jednym z podstawowych kontekstów każdej literatury narodowej jest jej szyfr zewnętrzny objawiający się w konstrukcji krajobrazu, na tle którego rozgrywają się wielkie wydarzenia historyczne i głęboko skryte dramaty osobiste świadków historii. Tak więc rozszyfrowanie znaków krajobrazu wydaje się być niezbędnym procesem poznawczym w ustaleniu tożsamości. Krajobraz jest obrazem świata, poprzez który można czytać i interpretować literaturę regionów przynależnych do siebie z najprzeróżniejszych racji historycznych. Widać to wyraźnie, kiedy prześledzi się dzieje tak wielokulturowego i światopoglądowo zróżnicowanego zjawiska, jakim jest kultura a ściślej literatura austriacka. Samo słowo krajobraz jest ideowo neutralne, w encyklopediach służy do określenia fragmentu powierzchni kuli ziemskiej, bez bliższej charakteryzacji jego pozageograficznych cech. Konkretyzacja cech krajobrazu następuje dopiero w momencie celowego wykorzystania tego pojęcia. W tym przypadku możemy wyróżnić dwa raczej luźno ze sobą związane znaczenia terminu krajobraz, pierwsze to krajobraz naturalny, drugie to krajobraz kulturowy. Wszelkie pozostałe konotacje tego słowa można sprowadzić do wymienionych znaczeń podstawowych, wszelako tylko pozornie, bowiem zachodzące na przestrzeni lat procesy zmian semantycznych spowodowały oderwanie się od terytorialnego znaczenia tego pojęcia jego cech abstrakcyjnych. W ten sposób powstały przymiotnikowo wzbogacone terminy, jak psychologiczny krajobraz duchowy, socjologiczny krajobraz polityczny lub estetyczny krajobraz literacki. Te abstrakcyjne krajobrazy są poniekąd emanacją krajobrazu kulturowego i jako produkty intelektu pozwalają się zinstrumentalizować, przez co tracą swój czysty, pozbawiony praktycznego zastosowania charakter. 
Obok asocjacji geograficznych słowo krajobraz wywołuje również skojarzenia artystyczne. Nazwy malarstwo krajobrazowe (Landschaftsmalerei) jako pierwszy użył, jeśli wierzyć wiarygodnemu skądinąd leksykonowi Brockhausa ${ }^{1}$, Albrecht Dürer, przyczyniając się tym samym do ukonstytuowania terminu estetycznego, stosowanego głównie w historii sztuki. Jednakoż również określenie malarstwo krajobrazowe, odbierane jako proste naśladownictwo natury, uwieloznaczniło się pod wpływem działań zewnętrznych, związanych ze społeczną rolą sztuki. Nie inaczej miała się sprawa z emancypacją kulturowego pojęcia krajobraz literacki. To, co we wczesnych wierszach o przyrodzie określano jeszcze mianem słownego malarstwa, mającego na celu odzwierciedlanie estetycznych walorów krajobrazu, zostało na skutek pozaestetycznych aspektów tego terminu podporządkowane ideowym strategiom poetologicznym.

Austriackie pejzaże kulturowe, a szczególnie krajobrazy literackie, doświadczają podobnych przeobrażeń semantycznych, ich pierwotny romantyczny charakter, związany z metafizyką przyrody, przekształca się wewnętrznie w okresie modernizmu, abstrahując coraz bardziej od swych barokowych źródeł zewnętrznego opisu. Współcześni artyści i pisarze zmieniają zasadniczo sposób widzenia świata, krajobraz plastyczny (zewnętrzny) przekształca się pod wpływem ich zabiegów estetycznych w krajobraz wewnętrzny (psychologiczny). Oczywiście stosunkowo łatwo przy pomocy dobranych przykładów zakwestionować zasygnalizowany tu proces internalizacji krajobrazu, tyle, że fakt ten ma, na skutek teorii Sigmunda Freuda, praktyki malarskiej Gustava Klimta, filozofii Ludwiga Wittgensteina, poezji Rainera Marii Rilkego, teatru Arthura Schnitzlera czy prozy Roberta Musila i Franza Kafki, w kulturze austriackiej bardziej widoczne znamiona niż w innych kulturach europejskich. Innymi słowy, transformacja krajobrazu stała się, by użyć tu określenia Eliasa Canettiego, austriackim sposobem „czytania świata” (Die Lesbarkeit der Welt)².

Jeśli z tego, intelektualnie nieco zawiłego punktu widzenia spojrzymy na określenie „krajobrazy habsburskie”, okaże się, że tkwi w nich klucz do rozszyfrowania świadomości dzieł literackich, które wyszły spod pióra najwybitniejszych pisarzy austriackich. Posługując się tym kluczem można otwierać kolejne warstwy znaczeniowe tych dzieł, od uogólniającej historiozofii, przez antropologię mentalności, po uwikłania w zbiorowej psychozie $\mathrm{i}$ indywidualnych kompleksach. O jednym wszelako należy przy tych interpretacjach faktów literackich pamiętać, krajobrazy habsburskie nie są pejzażami realnymi, i choć ciągle odwołują się do świata

${ }^{1}$ DTV-Brockhaus-Lexikon in 20 Bänden. Wiesbaden 1984. Bd. 10, s. 258.

2 Die Lesbarkeit der Welt. Elias Canettis Anthropologie und Poetik. Hrsg. von Stefan H. Kaszyński. Poznań 1984. 
rzeczywistego, budują w istocie z jego elementów świat, jak powiada Eliade ${ }^{3}$, mitycznych konotacji, lub, jak mówi Kołakowski ${ }^{4}$, wszechobecnych zależności mitycznych. To pisarz o galicyjskiej, a więc poniekąd austriackiej, proweniencji duchowej Bruno Schulz ${ }^{5}$ twierdził w swym eseju o mityzacji rzeczywistości, że za pomocą środków estetycznych wszelki opis literacki, a więc również krajobraz, uzewnętrznia swe zamocowanie mityczne, które nadaje mu ponadczasowy sens.

Znakomita większość pisarzy austriackich już od czasów romantyzmu buduje, podobnie jak prozaik Adalbert Stifter czy dramaturg Franz Grillparzer, krajobrazy literackie, które mają swe historyczne, ideowe i polityczne konteksty, przez co z góry narażone są na interpretacyjne nadużycia. Literatury narodowe, od czasu przyjęcia tego terminu w literaturoznawstwie europejskim, zawsze zorientowane były terytorialnie, a więc poniekąd również krajobrazowo. Tak więc krajobraz stanowi atrybut pozwalający na ich terytorialna, narodowa, mentalna, a nawet symboliczną lokalizację. Równocześnie krajobraz to, jak domniemywa historyk Reinhard Koselleck, przestrzeń wspólnych historycznych doświadczeń, plan, na którym dochodzi do budowania tożsamości poprzez uczestnictwo w wydarzeniach o bardzo zróżnicowanym społecznie charakterze. W krajobrazach habsburskich bardziej od cech narodowych wyróżnia się właśnie owa przestrzenna wspólnota doświadczeń.

Oczywiście byłoby metodologicznym nadużyciem porządkowanie literatur wyłącznie według ich krajobrazowej przynależności, dlatego też konserwatywny austriacki historyk literatury Josef Nadler ${ }^{7}$ przydał tej klasyfikacji wątpliwą antropologicznie kategorię szczepów etnicznych, rozpatrując dzieje literatury niemieckiej jako emanacje krajobrazów i szczepów germańskich. Tymczasem właśnie kultura austriacka, która mieści w sobie m.in. pierwiastki germańskie, słowiańskie, żydowskie czy węgierskie dokładnie zaprzecza teoriom narodowym Josefa Nadlera ${ }^{8}$. Więcej, wynika z niej, słusznie zreszta, że literatura austriacka nie jest literaturą narodowa, lecz literaturą wielonarodowa, którą zidentyfikować

${ }^{3}$ Mircea Eliade: Aspekty mitu. Przekład Piotr Mrówczyński. Warszawa 1998.

${ }^{4}$ Leszek Kołakowski: Obecność mitu. Wrocław 1994.

${ }^{5}$ Bruno Schulz: Mityzacja rzeczywistości. W: tenże: Opowiadania. Wybór esejów i listy. Wrocław 1989. S.365-368.

${ }^{6}$ Reinhard Koselleck: Semantyka historyczna. Wybór Hubert Orłowski, przekład Wojciech Kunicki. Poznań 2001. S.164.

${ }^{7}$ Josef Nadler: Literaturgeschichte der deutschen Stämme und Landschaften. Regensburg 1923.

8 Idee Nadlera skompromitował w latach sześćdziesiątych włoski literaturoznawca Claudio Magris w swej książce o micie habsburskim w literaturze austriackiej (C. Magris: Der Habsburgische Mythos in der österreichischen Literatur. Salzburg 1966). 
można częściowo przynajmniej przez terytorium i nadrzędną ideę państwową. Oba te elementy mieszczą się $\mathrm{w}$ metaforycznym rozumieniu krajobrazu habsburskiego, krajobraz to terytorium, a dom panujący Habsburgów to idea państwa ponadnarodowego.

Tak rozumiane krajobrazy habsburskie nie są pojęciem ideowo i politycznie neutralnym, zakłada ono przynależności terytorialne, które po pierwszej wojnie światowej były nie do przyjęcia przez powstałe na gruzach Monarchii Austro-Węgierskiej państwa narodowe. Habsburskie znaczy w skrócie będące we władaniu Habsburgów, jednak dynastia ta w czasie swego panowania w Cesarstwie Austriackim wielokrotnie zmieniała swój stosunek do wchodzących w jego skład narodów, stając się w końcu synonimem narodowego i kulturowego liberalizmu. Jako habsburski określa się jednak również pewien sposób bycia, styl życia, jakby powiedział Johann Wolfgang Goethe, obudowany został on charakterystycznymi biurokratycznymi instytucjami, dziwnym, nieadekwatnym do sytuacji rytuałem oraz pozornie niefrasobliwymi lub ironicznymi formami zachowań. Habsburski sposób myślenia i działania wyrażał się też poprzez specyficzną organizację przestrzeni i życia codziennego. O ile instytucje, budowle i rytuały habsburskie należą od dawna do przeszłości, o tyle zachowały one swoją ponadczasową żywotność w artystycznych i literackich manifestacjach austriackości. Dowodzą tego zarówno dzieła klasyków współczesności Musila, Brocha, Kafki bądź Doderera, jak i utwory autorów bliższych nam w czasie, by wymienić tylko znaną i w Polsce prozę Ingeborg Bachmann, Thomasa Bernharda lub Petera Handkego. Faktem zdumiewającym, choć bynajmniej niepozbawionym wewnętrznej logiki, jest kontynuowanie estetyki habsburskiej w książkach pisarzy w krajach wyzwolonych spod panowania Habsburgów, wystarczy wymienić Polskę, Węgry, Serbię, Czechy lub Ukrainę.

Wspomniane elementy habsburskie, $\mathrm{w}$ tym organizacja przestrzenna krajobrazu, są nie tylko podchwytywane przez literaturę, lecz stanowią jeden z głównych tematów mityzacyjnej transformacji. Ów estetyczny sposób przetwarzania krajobrazu habsburskiego nie jest bynajmniej procesem powierzchniowym, przeciwnie, sięga on w głąb struktury narracyjnej, determinując niejednokrotnie światopogląd całego utworu. By nie być gołosłownym, wystarczy wskazać na ontologiczną rolę krajobrazu w Zamku (Das Schloss) Franza Kafki, powieści pozornie dosyć odległej od habsburskich konotacji. O tym, że wykorzystana przez Kafkę atrapa habsburskiego krajobrazu, w którym to, co absurdalnie nierealne jest bardziej wiarygodne od rzeczywistości, może stanowić wyróżnik dla całej literatury austriackiej, o czym poświadczają mniej lub bardziej udane reprodukcje takiego krajobrazu w powieściach Roberta Musila Człowiek 
bez właściwości (Der Mann ohne Eigenschaften), Hermanna Brocha Kusiciel (Die Verzauberung), Heimito von Doderera Demony (Die Dämonen), Fritza Herzmanowsky'ego-Orlando Straszykoń w różanych sidłach (Der Gaulschreck im Rosennetz), Ingeborg Bachmann Malina i Thomasa Bernharda Wymazanie (Auslöschung).

W krótkich z konieczności rozważaniach teoretycznych nie sposób opisać całego bogactwa refleksji filozoficznych, ideologicznych i kulturoznawczych, ukrytych pod semantycznie wieloznacznym pojęciem krajobrazów habsburskich, dla jasności dyskursu można jednak sprowadzić jego walory do trzech zbiorczych kategorii wyróżniających, które, opatrzone analitycznymi aplikacjami, tłumaczą sens i znaczenie zastosowanego w opisie pojęcia.

\section{Kategorie krajobrazów habsburskich}

Kategoria historyczna: Krajobraz habsburski jest pojęciem historycznie uwarunkowanym, już od zarania kształtował się on pod wpływem wielu kultur, dynamika postrzegania jego znaków rozpoznawczych wiąże się ściśle z polityczną historią regionu środkowoeuropejskiego.

Kategoria mityczna: Krajobraz habsburski jest zjawiskiem dalece zmityzowanym, co znaczy, że rozważanie na jego temat jest w istocie ważniejsze od realnego opisu rzeczywistości. Fakt ten dotyczy w równym stopniu strategii autorskich, jak i sposobu recepcji zaszyfrowanych w krajobrazie znaczeń.

Kategoria lingwistyczna: Krajobraz habsburski jest przede wszystkim tworem językowym. Ideologizujące struktury lingwistyczne, zwane za Ludwigiem Wittgensteinem "grami językowymi", określają jego optykę (estetyka), wyrażają jego atmosferę (aura) oraz determinują jego funkcję (polityczna dyspozycyjność).

Wymienione tu kategorie nadrzędne dają sposobność do historycznego, ideowego i lingwistycznego opisu nieostrego logicznie pojęcia krajobrazu habsburski. Liczba domniemań, zwanych dla uproszczenia kategoriami, które mogą być pomocne w definiowaniu funkcji krajobrazu habsburskiego w literaturze, nie jest systemem zamkniętym i może ulegać powiększeniu w zależności od charakteru dzieła, w którym pejzaż habsburski decyduje o warstwie światopoglądowo znaczącej. Wszelako wyodrębnione tu z szerszego kontekstu znaczeniowego tezy zostały tak logicznie skonstruowane, by można je było wykorzystać przy analizie wewnątrztekstowych sprzeczności, które w utworach Roberta Musila, Franza Kafki, Eliasa Canettiego czy Thomasa Bernharda stanowią o intelektualnym 
wymiarze dzieła literackiego. Krajobrazy tych pisarzy są równocześnie zewnętrzne (Joseph Roth) i wewnętrzne (Georg Trakl), estetyczne (Hugo von Hofmannsthal) i psychologiczne (Arthur Schnitzler), ideowo określone (Hermann Broch) i całkowicie pozbawione określających właściwości (Robert Musil). Rozumieć je można odwołując się do historii idei, filozofii języka, psychologii głębi, estetyki narracji i kilku innych dziedzin instrumentalnie przydatnych w odkrywaniu intencji autorskich. Przytoczone tu tezy zostały zdefiniowane $\mathrm{w}$ taki sposób, by można było przy ich pomocy stwierdzić, że konstrukcje estetyczne utworów pisarzy austriackich wykorzystują elementy krajobrazu w celach pozaliterackich, zaś sprawa intencjonalnego czytania krajobrazu dotyczy w równym stopniu autorów i czytelników tych utworów. Znaczy to, że krajobrazy opowiadań Stiftera, powieści Rotha czy Doderera czytać można wprost jako manifestacje rzeczywistości zewnętrznej lub też dopatrywać się w nich ukrytych znaczeń światopoglądowych.

\section{Charakterystyka pierwsza}

Podkreślenie roli czytelnika w procesie ustalania pozaliterackich znaczeń krajobrazów habsburskich nie dowodzi bynajmniej niemocy pisarzy w ideologicznym czy zgoła politycznym kreowaniu świata przedstawionego, przeciwnie, osadzenie akcji utworów Rotha, Musila, Doderera, Fritscha, Eisenreicha lub Bernharda w krajobrazie austriackim, z wszystkimi jego ponadnarodowymi atrybutami, świadczy dowodnie o celowym wykorzystaniu krajobrazu jako znaku rozpoznawczego ideologii habsburskiej. Zmityzowany przez pisarzy krajobraz odwołuje się w swej warstwie głębinowej do ponadnarodowych idei państwowości Cesarstwa Austriackiego, widać to również w dziełach pisarzy, którzy jak Peter Handke, Gerhard Roth, Peter Turrini czy Robert Menasse z racji spóźnionej daty urodzenia znają Austrowęgry jedynie z kart historii.

Z perspektywy historyka literatury stosunkowo łatwo przyporządkować wymienionym wyżej kategoriom określone utwory literackie, w których zrealizowane zostały postulaty zawarte $\mathrm{w}$ tezach wyjaśniających. Można to uczynić diachronicznie w przekroju całej literatury austriackiej, można też synchronicznie, odwołując się do jednej epoki lub kierunku literackiego. Nie ma wątpliwości, że w każdej epoce znajdą się w Austrii pisarze, którym szczególnie bliska była tematyzacja krajobrazu. Bywają jednak tendencje literackie, jak ulubiona w Austrii „sztuka ojczyźniana” (Heimatkunst), w których programowe uwielbienie dla krajobrazu jest elementem kształtowania konserwatywnego światopoglądu, zręcznie wy- 
korzystywanego dla celów politycznych. Z tych samych powodów właśnie ta forma kształtowania świadomości zbiorowej spotkała się w Austrii z oporem środowisk literackich przeciwnych wszelkim formom estetycznej korupcji. Przykładem na postawę pierwszą może być konserwatywna dramaturgia Karla Schönherra lub proza Karla Heinricha Waggerla, postawę drugą odnaleźć można w społecznie progresywnych sztukach Wolfganga Bauera, mitoburczych powieściach Franza Innerhofera lub z lekka prześmiewczych tekstach Gerharda Amanshausera.

Jest rzeczą oczywistą, że nie wszyscy pisarze austriaccy wykorzystują krajobrazy dla umacniania ideologii habsburskiej, dotyczy to nie tylko poezji lirycznej Lenaua, Rilkego i Trakla lub opowiadań psychoanalitycznych Ferdinanda von Saara i Stefana Zweiga, choć niektóre powieści tego ostatniego ulegają urokowi tej ideologii, ale głównie twórczości modernistycznej i awangardowej, pryncypialne przeciwnej, jak wypadku „Wiener Gruppe", wszelkiej utylitarnej instrumentalizacji aktów artystycznych. Jednak przyjęty w literaturoznawstwie sposób czytania literatury austriackiej przez pryzmat krajobrazów habsburskich sprawia, że nawet eksperymentalne wiersze Hansa Carla Artmanna lub konkretne poezje Ernsta Jandla tłumaczyć można poprzez kontekst wspomnianych tu ideologemów.

\section{Charakterystyka druga}

Austriackie powieści historyczne dowodzą już od połowy XVIII wieku, że wzmożone zainteresowanie pisarzy estetyzacją krajobrazu habsburskiego przebiega równolegle do wzrostu międzynarodowego znaczenia domu panującego w Austrii. Istnieje też podkreślany przez Claudio Magrisa ${ }^{9}$ związek między terytorialną ekspansją Habsburgów a umacnianiem się samoświadomości pisarzy austriackich. To fakt oczywisty, zręcznie wspierany przez politykę kulturalną państwa od czasów cesarzowej Marii Teresy po ostatnie lata rządów Franciszka Józefa. W mniemaniu panujących literatura służyć winna kształtowaniu i umacnianiu tożsamości obywatelskiej $\mathrm{w}$ wielonarodowym państwie. O tym, że świadomość ta przyjęta została dobrowolnie lub pośrednio przez następujące po sobie pokolenia pisarzy, przekonać się można śledząc dzieje literatury austriackiej od XVIII wieku po lata nam współczesne.

Estetyka oświecenia była z natury rzeczy wrażliwa na uroki krajobrazu, jego metafizyczny aspekt podkreślał pośrednio autorytet władcy,

\footnotetext{
${ }_{9}$ Patrz przypis 8. (Magris).
} 
wielbiąc uroki pejzażu głosiło się pośrednio chwałę domu panującego, wiedzieli o tym nie tylko pisarze dworscy jak baron Joseph von Sonnenfels. Literatura austriacka za czasów reformatora cesarstwa Józefa II potrafiła zręcznie zaadaptować ideały światowego uniwersalizmu, głoszone w pismach Gottholda Ephraima Lessinga i Gottfrieda Herdera, dla własnych lokalnych potrzeb, wykorzystując ponadnarodowy charakter krajobrazu, który nie kojarzył się z żadną nacją, a jedynie z domem panującym Habsburgów. Echa tej postawy odbijają się jeszcze na początku XIX wieku w dramatach habsburskich klasyka literatury austriackiej Franza Grillparzera.

Kiedy to za sprawą Napoleona doszło w roku 1804 do konieczności utworzenia na gruzach I Rzeszy Niemieckiej samodzielnego Cesarstwa Austriackiego pozycja Habsburgów uległa wprawdzie osłabieniu, jednak aktywność kanclerza Metternicha nie pozwoliła na zdegradowanie roli Austrii w nowym ponapoleońskim porządku europejskim. Austria stała się mocarstwem regionalnym, ukierunkowanym na dominację w Europie Środkowej. To zmiana pozycji politycznej przyczyniła się też do legitymizacji krajobrazu habsburskiego jako substytutu narodowej ojczyzny. Intelektualnym wyrazem tej nowej sytuacji są nie tylko tragedie Grillparzera czy powieści Stiftera, ale również utwory pisarzy liberalnych, niekoniecznie sprzyjających absolutystycznemu modelowi państwa. Ich zwrot ku krajobrazowi realizuje wprawdzie biedermeierowską ideę ucieczki od rzeczywistości, jednak krajobraz wierszy Nicolausa Lenaua i Anastasiusa Grüna lub opowiadań Friedricha Halma jest w istocie swej krajobrazem umiejscowionym w Monarchii i przez nią się tłumaczącym.

Do zmiany $\mathrm{w}$ recepcji krajobrazu u pisarzy austriackich doszło dopiero w epoce modernizmu. Zewnętrzne oznaki upadku wartości, na których zbudowano wielonarodowe państwo Habsburgów, zostały przez literatów zinternalizowane m.in. przez słowne rysunki krajobrazu w impresjonistycznych wierszach Hofmannsthala lub ekspresjonistycznie poszarpanych relacjach lirycznych Trakla i Werfla, jeśli dodamy do tego upiorne krajobrazy Schnitzlera, Kubina czy Kafki, łatwo zrozumiemy, na czym polegał ten zwrot. Paradoks polega jednak na tym, że znakiem rozpoznawczym tych krajobrazów jest nadal ich habsburski charakter, tyle, że nie są to już pejzaże integracji, a obrazy destrukcji.

Najwyraźniej dostrzega się tę estetykę destrukcji krajobrazu u pisarzy o skomplikowanej przynależności narodowej, wywodzących się z obrzeży rozległej terytorialnie Monarchii, a więc w opowieściach galicyjskich Leopolda Sachera-Masocha i Josepha Rotha, obrazkach z Bukowiny Emila Franzosa lub odrealnionych portretach praskich ulic u Gustava Meyrinka, Paula Leppina i Leo Perutza, by nie odwoływać się nieustannie do mitycznego dzieła Franza Kafki. 
Proza wymienionego w kontekście galicyjskim Josepha Rotha jest $\mathrm{w}$ pewnym sensie łącznikiem między realnymi krajobrazami habsburskimi z czasów Monarchii i ich mityczną emanacją w nostalgicznych utworach tego autora, tworzonych po upadku Austro-Węgier. Jego napisana w roku 1932 ideologicznie zaprogramowana powieść Marsz Radetzky'ego (Radetzkymarsch), w której blask i upadek Monarchii wtopiony jest w rozległe krajobrazy od Słowenii, przez Morawy po Wiedeń i rodzinną Galicję, oddaje poprzez swą różnorodność współistniejących znaków kulturowych sens habsburskiej wspólnoty narodów. Książka ta powstała po rozpadzie tej wspólnoty jako duchowy testament habsburskiego modelu Europy Środkowej. Nostalgiczne krajobrazy Rotha, przetworzone intelektualnie i dopasowane do nowej rzeczywistości, bywają wykorzystywane, a niekiedy nawet nadużywane $\mathrm{w}$ różnych celach pozaliterackich przez austriackich polityków, również po drugiej wojnie światowej. Świadczą o tym rozliczne powieści Alberta Parisa Gütersloha, Heimito von Doderera, Gerharda Fritscha, Ingeborg Bachmann, Thomasa Bernharda, nie wspominając już szerokiej gamy twórców literatury popularnej (Alexander Lernet-Holenia, Gregor Rezzori, Jörg Mauthe, Peter Marginter, Herbert Rosendorfer), dla których krajobraz habsburski bywa znakiem firmowym literatury austriackiej.

Proces mityzacji krajobrazu habsburskiego, poniekąd za sprawą nostalgii do niespełnionych idei, przekroczył tymczasem granice Republiki Austriackiej i stał się też rozpoznawalną częścią składową utworów niektórych pisarzy w krajach będących niegdyś fragmentem habsburskiej wspólnoty narodów. Strategie idealizacji przeszłości przez odwoływanie się do habsburskich znaków kulturowych, zaszyfrowanych w krajobrazach, dostrzec można bez trudu w twórczości Polaków Andrzeja Kuśniewicza lub Andrzeja Stojowskiego ${ }^{10}$, czytelne odwołania do tych symbolicznych znaków spotkamy też u Węgrów, w tym w prozie György Konráda i Pétera Esterházy, w esejach czeskiego emigranta Milana Kundery, w błyskotliwych intelektualnie zapiskach pochodzącego z Serbii Danilo Kiša, a również w przewrotnych opowiadaniach Ukraińca Jurija Andruchowycza. Czym wytłumaczyć mitotwórczą siłę krajobrazu habsburskiego? Odpowiedź na to pytanie zakodowana została w trzech wzajemnie na siebie oddziaływujących warstwach znaczeniowych (historycznej, kulturowej i estetycznej) utworów literackich pisarzy o pogłębionej świadomości środkowoeuropejskiej.

${ }_{10}$ Pogłębioną i wielostronną analizę oddziaływania tego mitu w literaturze polskiej znajdziemy w książce austriackiego slawisty Aloisa Woldana pt. Mit Austrii w literaturze polskiej. Przekład Krzysztof Joachimczak i Ryszard Wojnakowski. Kraków 2002. 


\section{Charakterystyka trzecia}

Wizerunek krajobrazów habsburskich w literaturach środkowoeuropejskich ulegał pod wpływem estetyzacji powolnym, lecz symbolicznie znaczącym transformacjom, by w końcu oderwać się od swych geograficznych korzeni i zaistnieć jako wartość światopoglądowa. Przekształcenie się krajobrazu realnego w krajobraz mitycznego języka jest porównywalny ze znaczeniową zmianą podmiotu literackiego w sławnej noweli Przemiana (Die Verwandlung) Franza Kafki. Rzecz oczywista stała się za sprawą literatury rzeczą niepojętą. Przekształcenie się krajobrazu rzeczywistych odniesień $\mathrm{w}$ krajobraz językowych symboli prowadzi siłą rzeczy do zgoła odmiennych form recepcji tego zjawiska, wyizolowane ze swego geograficznego kontekstu elementy pejzażu podporządkowane zostają na skutek operacji estetycznych językowemu systemowi organizacji znaczeń, słowem, rzeczywistość realna zamienia się w rzeczywistość mitu. Krajobraz habsburski znaczy więcej niż realny „landszaft” Wiednia, Tyrolu czy Styrii. Krajobrazowi habsburskiemu przydana została w literaturze nadrealna wartość symboliczna. I między innymi dlatego habsburskie krajobrazy wyróżniają się wśród innych krajobrazów literackich szczególnym zagęszczeniem warstwy symbolicznej.

Pytanie, które się $\mathrm{w}$ takich razach nasuwa, dotyczy rozpoznawalności krajobrazu habsburskiego. Na czym polega jego odrębność? Odpowiedź na to dają niepowtarzalne cechy zewnętrzne, nasycone mitem symbole i specyficzne formy organizacji języka opisu. Elementy te razem wzięte tworzą jedyny w swym rodzaju habsburski system komunikacji symboliczno-werbalnej. Habsburska komunikacja kulturowa odróżnia się wyraźnie od innych np. pruskich czy rosyjskich systemów symbolicznych organizujących wyobraźnię zbiorową w Europie Środkowej. Niezależnie od stopnia zagęszczenia symbolicznego są krajobrazy habsburskie przede wszystkim krajobrazami kulturowymi, z racji historycznych stały się one fragmentami wielonarodowego państwa i jako takie zaanektowała je literatura.

Czytając dzieła pisarzy terytorialnie i duchowo związanych z Monarchią Habsburską niejako automatycznie utożsamiamy znaki krajobrazowe jako stosunek autorów do idei państwa. Tymczasem państwo owe $\mathrm{z}$ racji czysto praktycznych umiejscawiało w przestrzeni konkretne lub symboliczne znaki pomagające $\mathrm{w}$ identyfikacji, chodziło więc $\mathrm{w}$ gruncie rzeczy o państwową czytelność krajobrazu. Z tej też przyczyny ujednolicano optycznie nie tylko ważne gmachy, będące siedzibami instytucji rządowych, lecz również gmachy użyteczności publicznej, od kościołów przez cmentarze, pomniki po dworce, kawiarnie, na miejskich szaletach kończąc. Te same habsburskie żółte fasady zdobiły reprezentacyjną Rin- 
gstraße we Wiedniu i ratusz w zapadłym mieście prowincjonalnym. Znaki te stały się szczególnie po upadku Monarchii symbolami rozpoznawczymi idei habsburskiej i jako takie trafiły do dzieł literackich, tych dawnych u Musila, Rotha, Zweiga, i tych nowszych u Bachmann, Bernharda czy Haslingera. Jeden z najbardziej przekonywających obrazów ikonosfery habsburskiej nakreślił Joseph Roth w swej nostalgicznej noweli Popiersie cesarza (Die Büste des Kaisers, 1934), rysunek krajobrazowy tego tematycznie w przedwojennej Polsce osadzonego opowiadania oddaje istotę mitu habsburskiego we wszystkich jego wymiarach. Bohater noweli hrabia Morstin wspomina swe peregrynacje po utraconej Monarchii, która była jego symboliczną ojczyzną:

Kiedy tak podróżował wzdłuż i wszerz swej wielonarodowej ojczyzny, uderzały go przede wszystkim owe charakterystyczne znaki, które w nieodmiennie ten sam, a jednak różnobarwny sposób powtarzały się na wszystkich stacjach, na wszystkich kioskach, budynkach publicznych, szkołach i kościołach we wszystkich krajach cesarstwa. Żandarmi nosili wszędzie podobne kapelusze z piórami lub też takie same pożółkłe hełmy ze złoconym czubem i błyszczącym, podwójnym orłem habsburskim; drewniane drzwi c.k. trafiki były zawsze pomalowane w czarno-żółte, skośne pasy, urzędnicy skarbowi mieli wszędzie takie same zielone frędzle przy błyszczących szablach; w każdym garnizonie oficerowie piechoty spacerowali po promenadzie w błękitnych mundurowych kubrakach i czarnych wyjściowych spodniach, kawalerzyści nosili takie same czerwone spodnie, a artylerzyści ubierali do tego identyczne brązowokrwiste bluzy, wszędzie w całym rozległym i wielobarwnym cesarstwie każdego wieczora równo $\mathrm{z}$ wybiciem dziewiątej na zegarach kościelnych trąbiono na capstrzyk melodię, składającą się z pogodnie brzmiących pytań i smętnych odpowiedzi. Wszędzie spotykało sie takie same kawiarnie z okopconymi sklepieniami i mrocznymi niszami, w których siadywali szachiści podobni do upiornych ptaków (...). Niemal we wszystkich kawiarniach Monarchii snuł się na zesztywniałych nogach kasjer, z obowiązkową serwetą na rękach i bokobrodami na twarzy, była to zawsze ta sama odległa i pokorna kopia Najjaśniejszego Pana, do którego należały wszystkie kraje Korony, wszyscy żandarmi, urzędnicy skarbowi, wszystkie kioski, koleje, szlabany, wszystkie narody. A w każdym kraju śpiewano inne pieśni, chłopi nosili inne stroje, mówiono innymi, nieraz bardzo egzotycznymi językami ${ }^{11}$.

Ten nieco przydługawy cytat nie wymaga w zasadzie komentarza, jak rzadko który fragment literacki ilustruje on bowiem proces mityzacji krajobrazu za pomocą języka symboli. Oczywiście nostalgiczna aura tego cytatu odsuwa w cień wszelką próbę racjonalnego spojrzenia na istotę krajobrazów habsburskich, jednakoż dowodzi on niezbicie, iż metodami literackimi można zaczarować każda, nawet najbardziej optycznie nieciekawą rzeczywistość.

11 Joseph Roth: Popiersie cesarza. Tryptyk galicyjsko-austriacki. Przekład Stefan H. Kaszyński. Poznań 1996. S.26-27. 


\section{Mit odwróconego porządku}

Ikonosfera habsburskich krajobrazów, by posłużyć się tu zręcznym sformułowaniem historyków sztuki, wytworzyła emocjonalną formę akceptacji mitu austriackiego, która uzewnętrzniła się poprzez własną estetykę odbioru, u źródeł której legł system komunikacji kulturowej, zamieniający znaki plastyczne na sygnały językowe. A ponieważ krajobrazy literackie są w pierwszym rzędzie tworami językowymi, należy je porządkować nie tyle wedle ich plastycznych, ile ich lingwistycznych wzorów. Język pejzaży habsburskich nasycony jest sformułowaniami kulturowymi, które w podobnej konstelacji gdzie indziej nie występują. Po części wynika to z języka urzędowego Monarchii, po części zaś z głęboko w świadomości zbiorowej zakorzenionej wielojęzyczności tego obszaru. Wpływy z węgierskiego, czeskiego, polskiego, słoweńskiego, jidysz czy włoskiego na język literacki utworów pisarzy austriackich intelektualnie korzystnie odróżnia te utwory od dzieł autorów niemieckich, zauważył kiedyś, może w przypływie eleganckiej niefrasobliwości, Tomasz Mann ${ }^{12}$. Patrząc na habsburskie krajobrazy literackie od tej strony, można, bezwstydnie podpierając się chwilowo modną terminologią Jacquesa Derrida, przyjąć, że istotą tego pejzażu jest jego różnia (différance) ${ }^{13}$, zakłada ona bowiem w sposób naturalny zarówno wielość podmiotów i strategii opisu, jak i wielość interpretacji, tym wszelako sposobem docieramy do intencji, które przed siedemdziesięciu laty przyświecały pisarstwu Roberta Musila, a dla Ludwiga Wittgensteina stanowiły teoretyczny model opisu świata.

Zawierzając tezie Wittgensteina, że granice języka określają granice świata zarówno w zewnętrznym, jak i wewnętrznym znaczeniu tego sło$\mathrm{wa}^{14}$, to literatura austriacka, z natury wielojęzyczna i wielokulturowa, widzi świat szerzej i rozumie go głębiej, a co za tym idzie bardziej od innych literatur europejskich odpowiada na dramatycznie niejednoznaczne wyzwania moralne XX stulecia. Wzbogacone doświadczeniem ludzi kulturowego pogranicza powieści Musila i Kafki, dramaty Schnitzlera i Horvátha, wiersze Trakla i Celana, aforyzmy Krausa i Canettiego najpełniej oddają ducha semantycznie niejednoznacznych krajobrazów habsburskich, w których fakty są iluzja, a język sposobem na zaczarowanie rzeczywistości. I jeszcze jedna uwaga na zakończenie, krajobrazy habsburskie nie

12 Thomas Mann: Stockholmer Gesamtausgabe, Reden und Aufsätze. Bd.2. Frankfurt am Main 1965. S.812.

${ }^{13}$ Jacques Derrida: Różnia (différance). W: Drogi wspótczesnej filozofii. Red. Jerzy Siemek. Warszawa 1978. S.411.

${ }^{14}$ Ludwig Wittgenstein: Tractatus logico-philosophicus. Przekład. Bogusław Wolniewicz. Warszawa 1979. Teza 5,6. S.67. 
są jak widzieliśmy, wyłączną własnością literatury austriackiej, od literatury polskiej, węgierskiej czy czeskiej różni ją jednak fakt, że nie może się ona bez nich obejść, o tym świadczą nawet postmodernistyczne powieści Thomasa Bernharda, Petera Handkego, Roberta Menasse lub niepokojące moralnie i estetycznie sztuki teatralne Petera Turriniego i owianej sławą skandalizującej noblistki Elfriede Jelinek ${ }^{15}$. Programowa względność świata wartości tych utworów porównywalna jest ze względnością postrzegania rzeczywistości w prozie Brocha, Doderera lub Canettiego. Tyle tylko, że tam coś ponadczasowego z tej względności wynikało, ich diagnozy wychodzące od opisu krajobrazu sondowały przepaść egzystencji uwikłanej w historyczne konteksty, u współczesnych widać głównie zagubienie $\mathrm{w}$ chaosie znaczeń, w których krajobraz niczego nie porządkuje a świadomie rujnuje tożsamość. Każdą, również tak niejednoznaczną jak austriacka.

\section{Zusammenfassung}

\section{LITERARISCHE IDENTITÄTSCHIFFREN IN DEN HABSBURGISCHEN LANDSCHAFTEN}

Der Beitrag versucht durch die Beschreibung und Wortanalyse des Begriffs Habsburgische Landschaften zum Phänomen der in den Kulturwerken verschlüsselten österreichischen Identität durchzudringen. Neben der definitorischen Klarlegung des Begriffs wird auch eine theoretische Kategorisierung der Landschaften vom historischen, kulturgeschichtlichen und ästhetischen Standpunkt vorgenommen, um die Einsatzfähigkeit des Begriffs bei der Aufklärung der Identitätsfrage unter Beweis zu stellen. Die kulturgeschichtliche Aufschlüsselung des mystischen Identitätspotentials wird dann anhand der historisch angeordneten österreichischen Literaturwerke aus verschiedenen kulturgeschichtlichen Epochen durchgeführt. Unter den Autoren, die als Sinnträger der Identität angeführt werden, sind Philosophen wie Mach und Wittgenstein, Maler wie Klimt, und Tiefenpsychologen wie Freud, vor allem aber Schriftsteller wie Grillparzer, Musil, Broch, Kafka, Roth, Trakl, Canetti, Handke, Bernhard, Jelinek, Turrini und Menasse vertreten. Der Aufsatz liefert ein Erklärungsmodell, an dem die österreichische Identitätsgeschichte nachgewiesen werden kann.

15 Jenseits des Diskurses: Literatur und Sprache in der Postmoderne. Hrsg. von Albert Berger, Gerda Elisabeth Moser. Wien 1994. S.217-233. 